\title{
Zimbabwe: RTI screening methods for women are not cost- effective
}

Population Council

Follow this and additional works at: https://knowledgecommons.popcouncil.org/departments_sbsr-rh

Part of the Demography, Population, and Ecology Commons, International Public Health Commons, and the Women's Health Commons How does access to this work benefit you? Let us know!

\section{Recommended Citation}

"Zimbabwe: RTI screening methods for women are not cost-effective," FRONTIERS OR Summary. Washington, DC: Population Council, 1999. 


\section{Zimbabwe Reproductive Tract Infections}

\section{RTI Screening Methods for Women Are Not Cost-effective}

\author{
Existing methods for screening reproductive tract infections among family \\ planning clients are not cost-effective: laboratory tests are too costly, and \\ syndromic case management often leads to missed infections and \\ unnecessary treatment. Health programs should continue to emphasize \\ preventive measures—changing individual behavior and promoting \\ condom use.
}

\section{Background}

Reproductive tract infections (RTIs) are common in Zimbabwe. Many RTIs increase the risk of human immunodeficiency virus (HIV) infection. In 1998, the Zimbabwe National Family Planning Council (ZNFPC) conducted an OR study to assess the feasibility of adding RTI diagnosis and treatment services to its menu of services. The study population consisted of 1,634 clients at three ZNFPC clinics. Each client was asked about lower abdominal pain, vaginal discharge and other RTI symptoms, was examined for clinical signs of RTIs, and was given laboratory tests to confirm the accuracy of diagnosis based upon symptoms and signs.

\section{Findings}

- RTI prevalence. Laboratory tests found that 9 percent of all family planning clients had one or more of the sexually transmitted RTIs (gonorrhea, trichomoniasis, and chlamydia). These three RTIs have serious public health consequences. Most clients with RTIs ( $26 \%$ of all clients) had either candida or bacterial vaginosis, which are not sexually transmitted. Two-thirds of FP clients had none of the five RTIs assessed by laboratory tests.

- Applying clinical guidelines. The study assessed the use of national guidelines for diagnosing and treating RTIs when laboratory tests are unavailable. Referred to as "syndromic management," the guidelines direct providers to treat with drugs all common causes of the specific syndrome or the combination of clients' reported symptoms and clinical signs observed during a pelvic examination. Identifying RTIs based on the guidelines was not effective because:

$\rightarrow$ Symptoms did not correlate well with RTIs. More than one-third of the clients with one or more RTIs (detected by laboratory tests) had no symptoms, and thus were not diagnosed as infected using the syndromic approach. Conversely, 47 percent of the family planning clients who had RTI symptoms and clinical signs, and therefore were identified as infected under syndromic management, did not actually have any of the five tested RTIs.

$\$$ Service providers did not always follow the syndromic management guidelines. They treated only 53 percent of the women who complained of lower abdominal pain and 65 percent of those who reported vaginal discharge and had clinical signs of it. The rest of the women went untreated (some were, in fact, uninfected and did not need treatment). 
- Cost of interventions. None of the interventions studied is affordable to programs in low-resource settings. The lowest-cost intervention is to use syndromic management to evaluate only those FP clients seeking RTI services (see Table). However, this intervention has its drawbacks. In the study 75 percent of RTI cases were undetected and 56 percent of the women treated were misclassified as infected and thus received unnecessary treatment. Laboratory tests provide accurate diagnosis, but they are very expensive.

\section{Policy Implications}

- Most health agencies in developing countries lack the resources required to implement syndromic management of RTIs on a large scale. For example, in Zimbabwe estimated per capita spending on all health care was US\$47 in 1998. Applying syndromic management of RTIs to all FP clients would cost more than 10 percent of these scarce resources.

- The ineffectiveness of syndromic approach in identifying women with RTIs calls for a more concerted effort in advocating for and supporting the development of simpler and more costeffective laboratory tests.

- In the absence of more cost-effective approaches to RTI management, ZNFPC and other health agencies need to put greater emphasis on measures to reduce unsafe and unprotected sex, including condom promotion and counseling services to increase clients' perception of personal risk and knowledge of safer behaviors.

\section{Accuracy and Cost of Four RTI Diagnostic Models for FP Clients}

\begin{tabular}{lcccc}
\hline $\begin{array}{l}\text { Diagnostic Model } \\
(\mathrm{n}=1,623)\end{array}$ & $\begin{array}{c}\text { \# of Women } \\
\text { Correctly } \\
\text { Treated }\end{array}$ & $\begin{array}{c}\text { \# of Women } \\
\text { Given Drugs } \\
\text { Needlessly }\end{array}$ & $\begin{array}{c}\text { Total Cost } \\
\text { of Drugs } \\
\text { and Lab } \\
\text { Tests (US\$) }\end{array}$ & $\begin{array}{c}\text { Cost per Clinic } \\
\text { Client (US\$) }\end{array}$ \\
\hline $\begin{array}{l}\text { Syndromic approach for FP clients } \\
\text { seeking RTI services }(\mathrm{n}=410)\end{array}$ & 130 & 168 & 4,024 & 2.48 \\
\hline Syndromic approach for all FP clients & 337 & 298 & 8,605 & 5.30 \\
\hline $\begin{array}{l}\text { Syndromic approach for all FP clients, } \\
\text { with laboratory testing of clients with } \\
\text { RTI symptoms and clinical signs }\end{array}$ & 337 & 0 & 6,722 & 10.30 \\
\hline Laboratory testing for all FP clients & 524 & 0 & 41,819 & 25.77 \\
\hline
\end{tabular}

Zimbabwe National Family Planning Council. 1999. Demand for and Cost-Effectiveness of Integrating RTI/HIV Services with Clinic-based FP Services in Zimbabwe. For more information, contact: Population Council, P.O. Box 17643, Nairobi, Kenya.Tel.254-2-713-480; Fax: 254-2-713-479; E-mail: publications@popcouncil.or.ke.

This project was conducted with support from the U.S. AGENCY FOR INTERNATIONAL DEVELOPMENT under Contract Number CCP-3030-C-00-3008-00 and Cooperative Agreement Number HRN-A-00-98-00012-00. 